\title{
PERILAKU NUTRISI IBU HAMIL DENGAN HIPERTENSI DI RSUD BANGIL KABUPATEN PASURUAN
}

\author{
Tri Nataliswati ${ }^{1}$, Langen Basuki Abrianto ${ }^{2}$ \\ ${ }^{1}$ Dosen Jurusan Keperawatan Malang, Politeknik Kesehatan Kemenkes Malang \\ ${ }^{2}$ Prodi D-III Kep.Lawang, Politeknik Kesehatan Kemenkes Malang
}

\begin{abstract}
Hypertension in pregnancy is a disorder of unknown etiology, formerly called 'toxemia of pregnancy' or pre-eclampsia. One of the causes of hypertension in pregnant women is the wrong diet. The nutritional behavior of pregnant women during pregnancy is very important because the lack of knowledge, attitudes and actions of mothers in meeting their nutritional needs during pregnancy results in disturbances in pregnancy or the fetus. This study uses a descriptive method that aims to determine the nutritional behavior of pregnant women with hypertension in Bangil Hospital, Pasuruan Regency. Sampling using purposive sampling technique with a sample of 30 respondents. The instrument used is a closed questionnaire. The results of the study were the nutritional behavior of pregnant women with hypertension as many as 18 respondents (60\%) well behaved. It is expected that pregnant women will be more active in improving their behavior the better by seeking information about healthy nutritional needs for pregnant women with hypertension, for example actively participating in counseling activities and through information media such as books or magazines about nutrition for pregnant women.
\end{abstract}

Keywords : Behavior, Nutritional, Pregnancy Women, Hypertension

\section{A. PENDAHULUAN}

Perilaku dalam pemenuhan nutrisi menjadi salah satu hal yang penting diperhatikan pada masa kehamilan, asupan nutrisi selama kehamilan harus mendapat perhatian terutama mengenai jumlah kalori dan protein yang berguna untuk pertumbuhan janin dan kesehatan ibu. Pemenuhan nutrisi yang tidak sesuai dengan kebutuhan dapat menyebabkan anemi, abortus, partus prematurus dan pendarahan pasca persalinan.

Hipertensi atau tekanan darah tinggi adalah suatu kondisi medis dimana seseorang mengalami peningkatan tekanan darah secara kronis (dalam waktu yang lama) yang mengakibatkan angka kesakitan dan angka kematian. Seseorang yang mengalami tekanan darah tinggi atau hipertensi yaitu apabila tekanan darah sistolik $>140 \mathrm{mmHg}$ dan diastolik > $90 \mathrm{mmHg}$. Hipertensi karena kehamilan yaitu tekanan darah yang lebih tinggi dari 140/90 $\mathrm{mmHg}$ yang disebabkan karena kehamilan itu sendiri, memiliki potensi yang menyebabkan gangguan serius pada kehamilan. (Rukiyah, 2010).

Banyak sekali faktor penyebab hipertensi pada ibu hamil, salah satunya dari faktor diet/pola makan yang salah. Pengetahuan ibu tentang nutrisi selama kehamilan mempunyai peranan penting, kurangnya pengetahuan ibu tentang manfaat nutrisi selama hamil dapat menyebabkan bayi kekurangan nutrisi. Di samping itu pada masyarakat pedesaan masih terdapat adat kebiasaan berpantangan terhadap makanan sehingga dapat mempengaruhi sikap dan perilaku ibu dalam memenuhi kebutuhan nutrisinya. Jika ibu hamil tidak bisa mengatur pola makannya dengan benar guna 
memenuhi kebutuhan nutrisi untuk ibu dan bayinya maka akan membuat kesehatan ibu terganggu yang salah satunya bisa menyebabkan tekanan darahnya meningkat.

Menurut Hariyani (2011), tingginya tekanan darah tinggi merupakan gejala umum pada pre-eklamsia. Apabila tidak mendapatkan penanganan secara khusus bisa menyebabkan terjadinya kejang yang kemudian disusul dengan koma yang sering disebut dengan istilah eklamsia.

Angka Kematian Ibu (AKI) berdasarkan data resmi Survei Demografi Kesehatan Indonesia (SDKI) tahun 2007, terus mengalami penurunan. Pada tahun 2004 yaitu 270 per 100.000 kelahiran hidup, tahun 2005 yaitu 262 per 100.000 kelahiran hidup, tahun 2006 yaitu 255 per 100.000 kelahiran hidup, tahun 2007 menjadi 228 per 100.000 kelahiran hidup. Menurut Profil Kesehatan Indonesia (2010), walaupun sudah terjadi penurunan AKI di Indonesia, namun angka tersebut masih menempatkan Indonesia pada peringkat 12 dari 18 negara ASEAN dan SEARO (South East Asia Region, yaitu: Bangladesh, Bhutan, Korea Utara, India, Maladewa, Myanmar, Nepal, Timor Leste, dan lain-lain).

Penyebab kematian ibu di Indonesia masih disebabkan oleh trias klasik (perdarahan, infeksi dan eklamsi), dan non medis (status gizi, faktor ekonomi, sosial budaya). Salah satu kasus dari komplikasi kehamilan sebagai penyumbang AKI di Indonesia adalah hipertensi dalam kehamilan. Dalam Profil Kesehatan Indonesia (2008) diketahui bahwa eklampsia (24\%) adalah persentase tertinggi kedua penyebab kematian ibu setelah perdarahan (28\%). Kejang bisa terjadi pada pasien dengan tekanan darah tinggi (hipertensi) yang tidak terkontrol saat persalinan. Hipertensi ini dapat terjadi karena kehamilan dan akan kembali normal bila kehamilan sudah berakhir. Namun, ada juga yang tidak kembali normal setelah bayi lahir. Kondisi ini akan menjadi lebih berat bila hipertensi sudah diderita ibu sebelum hamil.

Cara yang paling efektif untuk mengurangi tekanan darah tinggi pada ibu hamil yaitu dengan menerapkan perilaku nutrisi yang baik dan sehat.

Menurut Hariyani (2011), tujuan diet pada ibu hamil dengan pre-eklamsia adalah untuk mengganti protein yang hilang akibat proteinuria, mengurangi retensi garam yang dapat meningkatkan tekanan darah, mencegah penambahan berat badan melebihi normal, memberi zat gizi secukupnya, serta mengurangi dan mencegah timbulnya faktor risiko lain atau penyakit penyulit baru pada saat kehamilan atau setelah melahirkan. Dan upaya untuk mendeteksi adanya pre-eklamsia dapat dilakukan dengan pemeriksaan tekanan darah rutin.

Dari hasil studi pendahuluan yang dilaksanakan pada bulan Maret 2014 di RSUD Bangil didapatkan hasil selama tahun 2013 jumlah ibu hamil dengan hipertensi yaitu 467 orang. Dengan rata-rata jumlah ibu hamil dengan hipertensi yaitu 38 orang tiap bulannya yang melakukan pemeriksaan di Poli Obgyn RSUD Bangil. Pada bulan Januari sampai Februari 2014 ibu hamil dengan hipertensi yang melakukan pemeriksaan berjumlah 74 orang.

Berdasarkan fenomena di atas perlu dilakukan penelitian untuk mengetahui perilaku nutrisi ibu hamil dengan hipertensi di RSUD Bangil Kabupaten Pasuruan 


\section{B. TINJAUAN PUSTAKA}

1. Konsep kehamilan

a. Definisi Kehamilan

Menurut Maryunani (2010), kehamilan adalah suatu keadaan dimana jani dikandung di dalam tubuh wanita, yang sebelumnya diawali dengan proses pembuahan dan kemudian akan diakhiri dengan proses persalinan.

b. Tanda-Tanda Positive Kehamilan / Tanda Pasti

Tanda-tanda pasti (positive sign) kehamilan merupakan tanda objektif yang didapatkan dari hasil pemeriksaan oleh provider. Apabila ditemukan salah satu tanda tersebut, maka diagnosa kehamilan dapat dibuat dengan pasti. Tanda pasti kehamilan adalah:

1) Mendengar bunyi jantung anak

Bunyi Jantung Anak (BJA) atau Denyut Jantung Janin (DJJ) dapat dideteksi dengan fetoskop atau doptone. Pada awal kehamilan, denyut jantung janin dapat diidentifikasi dengan menggunakan transvaginal ultrasound pada kehamilan 6 minggu. Sedangkan dengan USG transbominal dapat dideteksi mulai usia kehamilan 8 minggu. Denyut jantung janin juga terdengar pada usia kehamilan 10-12 minggu dengan menggunakan doptone sedangkan apabila menggunakan pinard's fetal stethoscope baru dapat terdengar mulai usia kehamilan 20-24 minggu.

2) Melihat dan meraba pergerakan dan bagian janin oleh pemeriksa

Apabila pemeriksa meraba ataupun melihat pergerakan anak maka hal tersebut termasuk salah satu tanda pasti kehamilan. Pergerakan janin dapat dirasakan oleh pemeriksa mulai usia kehamilan 20-24 minggu sedangkan bagian-bagian janin dapat dipalpasi mulai kehamilan 24 minggu.

3) Melihat rangka janin dengan sinar rontgen atau dengan ultrasound

Pemeriksaan dengan rontgen khususnya pada kehamilan muda akan berpengaruh terhadap janin sehingga pemeriksaan rontgen ini dianjurkan dilakukan setelah kehamilan lebih dari 18 minggu. Tetapi saat ini pemeriksaan dengan rontgen unutk menentukan tanda pasti kehamilan jarang dilakukan, sebagai gantinya penggunaan USG semakin banyak digunakan karena relative lebih aman jika dibandingkan penggunaan rontgen.

\section{Hipertensi Pada kehamilan}

Menurut Benson dan Pernoll's (2009), hipertensi dipicu kehamilan (pregnancyinduced hypertension, $\mathrm{PIH}$ ) adalah gangguan dengan etiologi yang tidak diketahui yang khusus pada wanita hamil. Dahulu disebut 'toksemia kehamilan' atau preeklampsia. PIH merupakan 80 persen dari semua kasus hipertensi pada kehamilan dan mengenai antara 3-8 persen pasien, terutama primigravida, pada kehamilan trimester kedua.

\section{a. Klasifikasi PIH}

Menurut Derek (2001), PIH diklasifikasikan menjadi: 


\section{1) Potensial PIH}

Tekanan darah pasien terukur meningkat $>30 \mathrm{mmHg}$ pada tekanan sistolik dan $>15$ mmHgpada tekanan diastolik di atas tekanan diastolik basal. Hal ini harus dianggap sebagai peringatan akan terjadinya $\mathrm{PIH}$, dan pasien harus diperiksa lebih sering oleh tenaga kesehatan profesional.

2) PIH Ringan

Tekanan darah diastolik pasien 90-99 $\mathrm{mmHg}$, dan kenaikan ini paling sedikit terdeteksi dalam dua kali pemeriksaan yang sekurang-kurangnya berselang 6 jam. Urin tidak menunjukkan protein signufikan (>30 mg/dl). $\mathrm{PIH}$ ringan hanya memberikan resiko sedikit bagi ibu atau janin.

3) PIH Sedang

Tekanan darah pasien terletak antara 140-170/100-110, yang dikonfirmasi dalam dua kali pemeriksaan berturut-turut setelah istirahat. Jika didapati protein urin signifikan )>30 dan $>300 \mathrm{mg} / \mathrm{dl}$ ), kategori ini berubah menjadi PIH berat.

4) PIH Berat (juga dikenal sebagai pre-eklampsia)

Tekanan darah pasien melebihi 170/110 dan/atau terdapat proteinuria nyata. PIH berat mengenai kira-kira 1 persen primigravida.

5) Eklampsia Iminens

Di samping tada-tanda PIH berat, pasien juga mengeluh sakit kepala berat, penglihatan kabur atau nyeri epigastrik dan hiperrefleksia.

\section{Nutrisi Ibu Hamil}

\section{b. Pengaruh Gizi pada Kehamilan}

Keadaan gizi ibu sebelum hamil dan selama hamil mempengaruhi status gizi ibu dan bayi. Pertumbuhan dan perkembangan janin sangat dipengaruhi oleh asupan gizi ibu, karena kebutuhan gizi janin berasal dari ibu. Tujuan penatalaksanaan gizi pada wanita hamil adalah untuk mencapai status gizi yang optimal sehingga ibu menjalani kehamilan dengan aman, melahirkan bayi dengan potensi fisik dan mental yang baik. Berbagai risiko dapat terjadi jika ibu mengalami kurang gizi, diantaranya adalah perdarahan, abortus, bayi lahir mati, bayi lahir dengan berat rendah, kelainan kongenital, retardasi mental, dan lain sebagainya.

Perempuan yang mengalami kekurangan gizi sebelum hamil atau selama minggu pertama kehamilan memiliki resiko lebih tinggi melahirkan bayi yang lebih mengalami kerusakan otak dan sumsum tulang karena pembentukan sistem saraf sangat pekan pada 2-5 minggu pertama. Ketika seorang perempuan mengalami kekurangan gizi pada trimester terakhir maka cenderung akan melahirkan bayi dengan berat badan lebih rendah $(<2500$ gram), hal ini dikarenakan pada masa ini janin akan tumbuh dengan sangat cepat dan terjadi penigmbunan jaringan lemak.

\section{c. Kebutuhan Gizi Ibu Selama Hamil}

Kebutuhan gizi ibu selama ibu hamil meningkat karena selain diperlukan untuk memenuhi kebutuhan gizi ibu juga diperlukan untuk janin yang dikandungnya. 
Pemenuhan gizi selama hamil juga diperlukan untuk persiapan ASI serta tumbuh kembang bayi. Kebutuhan gizi ibu hamil pada setiap trimester berbeda, hal ini disesuaikan dengan pertumbuhan dan perkembangan janin serta kesehatan ibu. Pemenuhan kebutuhan gizi pada trimester pertama lebih mengutamakan kualitas daripada kuantitas. Hal ini dikarenakan pada masa ini sedang terjadi pembentukan sistem saraf, otak, jantung dan organ reproduksi janin, selain itu pada masa ini tidak sedikit ibu yang mengalami mual muntah sehingga tidak memungkinkan untuk memenuhi kebutuhan gizi secara kuantitas. Pemenuhan gizi pada trimester II dan III, selain memperhatikan kualitas juga harus terpenuhi secara kuantitas.

Bahan pangan yang digunakan untuk memenuhi kebutuhan gizi ibu hamil harus meliputi enam kelompok, yaitu makanan yang mengandung protein baik hewani maupun nabati, susu dan olahannya, sumber karbohidrat baik dari roti ataupun biji-bijian, buah dan sayur yang tinggi kandungan vitamin $\mathrm{C}$, sayuran berwarna hijau tua, serta buah dan sayur lain.

\section{d. Diet Hipertensi}

Diet yang dikenal saat ini di negara maju bagi pasien-pasien penderita hipertensi adalah diet DASH (Dietary Approach do Stop Hypertension) yang merupakan diet sayuran serta buah yang banyak mengandung serat pangan (30 gram/hari) dan mineral tertentu (kalium, magnesium serta kalsium) sementara asupan garamnya dibatasi.

Faktor-faktor non-diet yang dapat memperberat hipertensi seperti kegemukan, kebiasaan merokok, kurang istirahat, stres yang berlebihan (distress) dan kebiasaan minum minuman keras harus diatasi, sementara kebiasaan baru yang dapat mengendalikan darah seperti olahraga aerobik yang teratur, relaksasi atau meditasi, dan pendekatan spiritual sangat dianjurkan.

Prinsip diet yang berhubungan dengan pencegahan hipertensi mencakup:

1) Upaya mempertahankan berat badan yang ideal/normal menurut tinggi badan dengan IMT yang tidak melebihi 22 dan lingkaran perut yang tidak lebih dari $90 \mathrm{~cm}$ pada laki-laki dan $80 \mathrm{~cm}$ pada wanita.

2) Penerapan diet DASH yang kaya serat pangan dan mineral tertentu di samping diet rendah garam, rendah kolesterol lemak terbatas serta diet kalori seimbang menurut penyakit penyertanya (hipertensi, dislipidemia serta diabetes melitus).

3) Membatasi asupan garam dapur hingga 3 gram./hari dengan memperhatikan pemberian mineral seperti kalsium, kalium dan magnesium menurut angka kecukupan gizi (AKG).

4) Membatasi bahan aditif pangan yang kaya akan atrium (MSG, sodium bikarbonat, sodium nitrit, sodium benzoat) termasuk makanan $7 \mathrm{~S}$ (snack, saus, sup yang dikalengkan, salted meat/fish, smoked meat/fish, seasonigs, dan sauerkraut)

5) Olahraga aerobik secara teratur. 


\section{METODE PENELITIAN}

Desain penelitian yang digunakan dalam penilitian ini adalah deskriptif, untuk mendapatkan gambaran perilaku nutrisi ibu hamil dengan hipertensi di RSUD Bangil Kabupaten Pasuruan.

Populasi dalam penelitian ini adalah seluruh ibu hamil dengan hipertensi yang melakukan pemeriksaan kehamilan di RSUD Bangil Kabupaten Pasuruan sejumlah 74 orang dan sampel yang diambil sejumlah 30 orang dengan menggunakan purposive sampling.

Pada proses pengambilan data, peneliti melakukan pendekatan kepada calon responden dan memeriksa tekanan darahnya. Peneliti menjelaskan maksud dan tujuan dari penelitian kepada calon responden kemudian memberikan informed consent kepada calon responden yang menyetujui, kemudian peneliti memberikan kuisioner kepada responden dan menjelaskan cara pengisiannya serta mendampinginya bila ada yang tidak dimengerti oleh responden berkaitan dengan pengisian kuesioner.

Setelah kuesioner terkumpul kemudian jawaban diberi skor, untuk jawaban benar diberi skor satu (1) dan untuk jawaban salah diberi skor nol (0). Kemudian total jawaban benar dijumlahkan dan dikalikan dengan jumlah soal.

Hasil diprosentasekan menggunakan rumus Setiadi (2007), kemudian diinterpretasikan/dikategorikan menggunakan kriteria kualitatif Arikunto (2006), yaitu sangat baik (76-100\%), baik (56-75\%), cukup (40-55\%), dan kurang baik $(<40 \%)$. kemudian data yang sudah diolah, disajikan menggunakan tabel distibusi frekuensi dan dinarasikan

\section{HASIL PENELITIAN}

Tabel 1 Distribusi Frekuensi Responden Berdasarkan Umur Ibu Hamil Dengan Hipertensi Di RSUD Bangil Kabupaten Pasuruan 21-25 Juli 2014.

\begin{tabular}{|c|c|c|}
\hline Umur & Jumlah $(\mathbf{n}=\mathbf{3 0})$ & Persentase (\%) \\
\hline$\leq 20$ th & 0 & 0 \\
$21-30$ & 15 & 50 \\
$31-40$ & 12 & 40 \\
$\geq 41$ & 3 & 10 \\
\hline Total & 30 & 100,0 \\
\hline
\end{tabular}

Berdasarkan tabel 1 dapat diketahui bahwa 15 responden (50\%) berumur 21 - 30 tahun. 
Tabel 2 Distribusi Frekuensi Responden Berdasarkan Pendidikan Ibu Hamil Dengan Hipertensi Di RSUD Bangil Kabupaten Pasuruan 21-25 Juli 2014.

\begin{tabular}{|l|c|c|}
\hline \multicolumn{1}{|c|}{ Pendidikan } & Jumlah $(\mathbf{n}=\mathbf{3 0})$ & Persentase (\%) \\
\hline SD & 8 & 27 \\
SMP & 6 & 20 \\
SMA/SMK & 13 & 43 \\
PT & 3 & 10 \\
\hline \multicolumn{1}{|c|}{ Total } & 30 & 100,0 \\
\hline
\end{tabular}

Berdasarkan tabel 2 dapat diketahui bahwa 13 responden (43\%) berpendidikan SMA/SMK.

Tabel 3 Distribusi Frekuensi Responden Berdasarkan Pekerjaan Ibu Hamil Dengan Hipertensi Di RSUD Bangil Kabupaten Pasuruan 21-25 Juli 2014.

\begin{tabular}{|l|c|c|}
\hline \multicolumn{1}{|c|}{ Pekerjaan } & Jumlah $(\mathbf{n = 3 0 )}$ & Persentase (\%) \\
\hline Tidak kerja & 13 & 43 \\
Swasta & 9 & 30 \\
Wiraswasta & 5 & 17 \\
PNS & 3 & 10 \\
\hline \multicolumn{1}{|c|}{ Total } & 30 & 100,0 \\
\hline
\end{tabular}

Berdasarkan tabel 3 dapat diketahui bahwa 13 responden (43\%) tidak bekerja.

Tabel 4 Disribusi Frekuensi Responden Tentang Perilaku Nutrisi Ibu Hamil Dengan Hipertensi Di RSUD Bangil Kabupaten Pasuruan 21-25 Juli 2014.

\begin{tabular}{|c|c|c|}
\hline Kategori & Jumlah $(\mathbf{n}=\mathbf{3 0})$ & Persentase (\%) \\
\hline Sangat Baik & 3 & 10 \\
Baik & 18 & 60 \\
Cukup & 9 & 30 \\
Kurang Baik & 0 & 0 \\
\hline Total & 30 & 100,0 \\
\hline
\end{tabular}

Berdasarkan tabel 4 dapat diketahui bahwa 18 responden $(60 \%)$ memiliki perilaku nutrisi ibu hamil dengan hipertensi dalam kategori baik. 
Tabel 5 Tabel Silang Perilaku Nutrisi Ibu Hamil Dengan Hipertensi Di RSUD Bangil Kabupaten Pasuruan dengan Karakteristik Responden

\begin{tabular}{|l|c|c|c|}
\hline \multicolumn{1}{|c|}{ Kategori } & Umur & Pendidikan & Pekerjaan \\
\hline Sangat Baik & $32 \& 35$ & PT & PNS \\
\hline Baik & $21-40$ & $\begin{array}{c}\text { SMP } \\
\text { SMA/SMK }\end{array}$ & Swasta \\
\hline Cukup & $31-40$ & SMA/SMK & Tidak kerja \\
\hline
\end{tabular}

\section{E. PEMBAHASAN}

Berdasarkan tabel diatas diketahui bahwa perilaku nutrisi ibu hamil dengan hipertensi sebagai berikut:

\section{Sebagian kecil responden sebanyak 3 ibu hamil (10\%) masuk kategori sangat} baik.

Data karakteristik responden menunjukkan 3 ibu hamil tersebut berumur 32 tahun dan 35 tahun. Menurut Notoatmodjo (2010), semakin cukup umur, tingkat kematangan dan kekuatan seseorang akan lebih matang dalam berfikir dan bekerja. Hasil tersebut sesuai dengan teori, semakin bertambahnya umur kamampuan berfikir seseorang semakin matang sehingga semakin banyak pula pengetahuan yang dimiliki.

Data karakteristik responden menunjukkan 3 ibu hamil berpendidikan PT (Perguruan Tinggi). Menurut Wahid (2007), tidak dapat dipungkiri bahwa semakin tinggi pendidikan seseorang semakin mudah pula mereka menerima informasi dan pada akhirnya semakin banyak pula pengetahuan yang dimilikinya. Dilihat dari hasil penelitian ibu hamil tersebut berpendidikan PT (Perguruan Tinggi) dimana memiliki daya berfikir yang baik sehingga bisa menerima dan memahami infomasi dengan mudah dan pengetahuan yang dimilikinya pun semakin banyak.

Data karakteristik responden menunjukkan 3 ibu hamil pekerjaannya adalah PNS. Menurut Notoatmodjo (2010), seorang yang bekerja pengetahuannya akan lebih luas dan dengan bekerja orang mampu mempunyai banyak informasi dan pengalaman. Hasil tersebut menunjukkan bahwa 3 ibu hamil itu memiliki pekerjaan yang sangat baik sehingga pengetahuan yang dimiliki sangat banyak yang didukung dari pengalaman selama bekerja, sehingga mendorong memiliki perilaku yang sangat baik.

\section{Sebagian besar responden sebanyak 18 ibu hamil (60\%) masuk kategori baik.}

Diketahui bahwa sebanyak 12 ibu hamil (40\%) berumur antara 31-40 tahun. Menurut Wahid (2007), bertambahnya umur seseorang akan terjadi perubahan pada aspek psikologis atau mental taraf berfikir seseorang semakin matang dan dewasa. Dilihat dari hasilnya, $18 \mathrm{ibu}$ hamil tersebut rata-rata berumur antara 31-40 tahun dimana seseorang dengan umur tersebut kemampuan berfikirnya sudah lebih matang dan dewasa sehingga bisa memilih hal-hal yang baik dan sehat bagi hidupnya.

Diketahui bahwa sebanyak 13 ibu hamil (43\%) berpendidikan SMA/SMK. Menurut Wahid (2007), pendidikan berarti bimbingan yang diberikan oleh 
seseorang pada orang lain terhadap suatu hal agar mereka dapat memahami. Tidak dapat dipungkiri bahwa semakin tinggi pendidikan seseorang semakin mudah pula mereka menerima informasi dan pada akhirnya semakin banyak pula pengetahuan yang dimilikinya, sebaliknya jika tingkat pendidikan seseorang rendah akan menghambat sikap seseorang dalam penerimaan innformasi dan nilai-nilai yang baru diperkenalkan. Menurut peneliti berdasarkan hasil yang didapat dan teori yang ada, hasil tersebut sesuai jika seseorang dengan tingkat pendidikan yang tinggi memiliki cara berfikir yang baik dan mudah memahami sehingga memiliki pengetahuan yang luas yang didapat dari informasi-informasi yang mudah diterimanya dan saat berada di bangku sekolah.

Diketahui bahwa sebanyak 9 ibu hamil (30\%) pekerjaannya swasta, sebagian kecil yaitu sebanyak 3 ibu hamil (10\%) pekerjaannya PNS. Menurut Notoadmodjo (2010), seorang yang bekerja pengetahuannya akan lebih luas dan dengan bekerja orang mempunyai banyak informasi dan pengalaman. Menurut peneliti, orang yang bekerja memiliki banyak informasi yang didapat saat bekerja dengan saling bertukar informasi dengan rekan kerja dan dari pengalaman selama bekerja sehingga pengetahuan yang dimiliki lebih banyak.

\section{Terdapat 9 ibu hamil (30\%) masuk kategori cukup.}

Diketahui bahwa sebanyak 12 ibu hamil (40\%) berumur antara 31-40 tahun. Menurut Wahid (2007), bertambahnya umur seseorang akan terjadi perubahan pada aspek psikologis atau mental taraf berfikir seseorang semakin matang dan dewasa. Meskipun teori mengatakan seperti itu, namun pada hasil penelitian 9 ibu hamil tersebut masuk dalam kategori pengetahuan cukup karena tidak semua pertanyaan kuesioner mampu dijawab dengan benar sehingga pada rentang umur antara 31-40 tahun belum pasti seseorang memiliki pengetahuan yang luas.

Diketahui bahwa sebanyak 13 ibu hamil (43\%) berpendidikan SMA/SMK. Menurut Wahid (2007), tidak dapat dipungkiri bahwa semakin tinggi pendidikan seseorang semakin mudah pula mereka menerima informasi dan pada akhirnya semakin banyak pula pengetahuan yang dimilikinya. Hasil terbanyak menunjukkan 13 ibu hamil berpendidikan SMA/SMK tetapi 9 ibu hamil tersebut masuk kategori perilaku yang cukup. Hal itu menunjukkan tidak pasti orang dengan pendidikan tinggi mampu dengan mudah menerima dan memahami informasi sehingga pengetahuan yang dimiliki juga banyak seperti pada teori karena pengetahuan yang dimiliki.

Data karakteristik responden menunjukkan $13 \mathrm{ibu}$ hamil tersebut tidak bekerja. Menurut Notoatmodjo (2010) seorang yang bekerja pengetahuannya akan lebih luas dan dengan bekerja orang mampu mempunyai banyak informasi dan pengalaman. Berdasarkan hasil penelitian 9 ibu hamil yang masuk dalam kategori perilaku yang cukup tersebut tidak memiliki pekerjaan sehingga masih belum mampu menjawab semua pertanyaan kuesioner dengan benar dan hal tersebut sesuai dengan teori. Namun hal tersebut belum mutlak karena meskipun tidak bekerja jika mampu menggunakan waktu yang dimiliki untuk aktif dalam mencari informasi dan ikut serta dalam kegiatan yang bemanfaat seperti penyuluhan maka informasi yang dimilikinya pun banyak sehingga pengetahuan yang dimiliki juga banyak 


\section{F. PENUTUP}

Berdasarkan hasil penelitian mengenai Perilaku Nutrisi Ibu Hamil dengan Hipertensi Di RSUD Bangil Kabupaten Pasuruan diketahui bahwa sebagian besar responden sebanyak 18 responden $(60 \%)$ memiliki perilaku yang baik.

Bagi responden Diharapkan ibu hamil lebih aktif dalam meningkatkan pengetahuan atau mencari informasi tentang kebutuhan nutrisi yang sehat bagi ibu hamil dengan hipertensi misal aktif mengikuti kegiatan penyuluhan dan melalui media informasi seperti buku atau majalah tentang gizi ibu hamil sehingga bisa lebih memahami, bisa memilih dan memilah sumber makanan yang baik dan sehat untuk kehamilannya serta mampu menerapkannya dalam kehidupan sehari-hari supaya dapat memungkinkan memiliki perilaku nutrisi yang baik.

\section{G. DAFTAR PUSTAKA}

Adriani, Wirjatmadi. 2012. Peranan Gizi dalam Siklus Kehidupan. Jakarta: Prenada Media Group.

Almatsier Sunita. 2010. Penuntun Diet Edisi Baru. Jakarta: Gramedia Pustaka Utama

Bensan, Ralph C. 2008. Buku Saku Obstetri \& Ginekologi. Jakarta: EGC.

Febry, Nurul, Ibnu. 2013. Ilmu Gizi untuk Praktisi Kesehatan. Yogyakarta: Graha Ilmu.

Hartono, Andry. 2006. Terapi Gizi dan Diet Rumah Sakit Edisi 2. Jakarta: EGC.

Indrayani, 2011. Buku Ajar Asuhan Kehamilan. Jakarta: Trans Info Media.

Maryuani Anik, 2010. Biologi Reproduksi dalam Kebidanan. Jakarta: Trans Info Media.

Nursalam. 2008. Konsep dan Penerapan Metodologi Penelitian Ilmu Keperawatan. Jakarta: Salemba Medika.

Proverawatai Atikah dan Asfuah Siti. 2010. Buku Ajar Gizi untuk Kebidanan. Yogyakarta: Nuha Medika.

Rudianto F. Budi. 2013. Menaklukan Hipertensi dan Diabetes. Yogyakarta: Sakkhasukma.

Soekidjo Notoatmodjo. 2010. Ilmu Perilaku Kesehatan. Jakarta: Rineka Cipta.

Soenanto Hardi. 2009. 100 Resep Sembuhkan Hipertensi, Asam Urat, dan Obesitas. Jakarta 